\title{
Implikasi Peraturan KPU Nomor 36 Pasal 36 Tahun 2018 pada Pemilu 2019 dalam Perspektif Maqashid Syariah
}

\author{
Muhammad Izzi ${ }^{1 *}$ \\ ${ }^{1}$ UIN Raden Fatah Palembang, Indonesia
}

\begin{abstract}
Abstrak: Penelitian ini bertujuan untuk menganalisis faktor-faktor yang melatarbekakangi permasalahan yang terjadi pada para anggota penyelenggara Pemilu 2019 dengan melihat dari perspektif Maqashid Syariah terhadap implikasi Peraturan KPU Nomor 36 Pasal 36 Tahun 2018 tentang persyaratan menjadi anggota Panitia Pemilihan Kecamatan (PPK) dan Panitia Pemungutan Suara (PPS), dan anggota Kelompok Penyelenggara Pemungutan Suara (KPPS) pada Pemilu serentak 2019. Penelitian ini menggunakan penelitian hukum normatif, metode pendekatan dalam penelitian ini menggunakan pendekatan kasus (case approach) dan pendekatan konseptual (conseptual approach). Penelitian ini menyimpulkan bahwa Peraturan KPU Nomor 36 Pasal 36 Tahun 2018 memiliki kemudaratan dan mafsadah, kemudian dari 5 prinsip Maqashid adDharuriyah juga tidak dapat dijaga dan dipelihara seperti Hifz ad-din (memelihara Agama), Hifdz an-nafs (memelihara Jiwa), Hifz al-aql (memelihara akal), hifz an-nasab (memelihara keturunan), dan Hifz al-maal (memelihara harta).
\end{abstract}

Kata Kunci: pemilu, peraturan KPU, maqashid syariah

\begin{abstract}
This study aims to analyze the factors behind the problems that occurred to the members of the 2019 Election organizers by looking from the perspective of Maqashid Syariah on the implications of KPU Regulation Number 36 Article 36 of 2018 concerning the requirements to become members of the District Election Committee (PPK) and the Voting Committee (PPS), and members of the Voting Organizing Group (KPPS) in the 2019 simultaneous elections. This research uses normative legal research, the approach method in this study uses a case approach and a conceptual approach. This study concludes that KPU Regulation Number 36 Article 36 of 2018 has disadvantages and mafsadah, then from the 5 principles of Maqashid ad-Dharuriyah also cannot be maintained and maintained such as Hifz ad-din (maintaining Religion), Hifdz an-nafs (maintaining the soul), Hifz al-aql (maintaining reason), hifz an-nasab (maintaining offspring), and Hifzal-maal (maintaining property).
\end{abstract}

Keywords: elections, KPU regulations, maqashid sharia

\section{Pendahuluan}

Indonesia adalah Negara Demokrasi yaitu negara yang menganut bentuk dan sistem pemerintahan oleh rakyat. Untuk menjalankan demokrasi tersebut maka rakyat memiliki hak dan kewajiban untuk memilih anggota Dewan
Perwakilan Rakyat (DPR), Dewan Perwakilan Daerah (DPD), Dewan Perwakilan Rakyat Daerah (DPRD), Presiden dan Wakil Presiden, yang diselenggarakan pada Pemilihan Umum. Pemilihan umum secara langsung oleh rakyat merupakan sarana perwujudan kedaulatan rakyat guna

\footnotetext{
* Corresponding Author: Muhammad Izzi (muhammadizzy15@gmail.com). UIN Raden Fatah Palembang, Indonesia
} 
menghasilkan pemerintahan Negara yang demokratis berdasarkan Pancasila dan UndangUndang Dasar 1945. Undang-Undang Dasar 1945 dalam Pasal 1 ayat (2) menyatakan bahwa kedaulatan berada ditangan rakyat dan dilaksanakan menurut Undang-Undang Dasar.

Pemilihan Umum 2019 berbeda dengan Pemilu sebelumnya, yang mana Pemilu 2019 merupakan Pemilu serentak pertama di Indonesia dalam sejarah. Selain memilih Presiden dan Wakil Presiden, Pemilu 2019 juga menjadi momen bagi rakyat Indonesia untuk memilih anggota DPR, DPD, DPRD Provinsi, dan DPRD Kabupaten/Kota. Sejarah digelarnya Pemilu serentak berawal dari aksi Effendi Ghozali dan Koalisi Masyarakat untuk Pemilu serentak. Pada 2013 mereka menggugat UU No 42 Tahun 2008 tentang Pilpres ke Mahkamah Konstitusi. Gugatan itu teregister dengan Nomor 14/PUU-XI/2013. Alasan mereka sederhana, penyelenggaraan Pemilu serentak lebih efisien baik dari segi waktu maupun biaya. Singkatnya, MK mengabulkan sebagian gugatan tersebut. Majelis Hakim MK membatalkan Pasal 3 Ayat 5, Pasal 12 Ayat 1 dan 2, Pasal 14 Ayat 2 dan Pasal 112 Undang-Undang Pilpres yang mengatur pelaksanaan Pilpres 3 bulan setelah pelaksanaan Pileg alias tidak serentak. Akibat putusan itu, pemerintah melalui Kementrian Dalam Negeri (KEMENDAGRI) langsung menyusun Undang-Undang Pemilu yang baru dengan memasukkan ketentuan Pemilu serentak. Selanjutnya, Presiden Joko Widodo mengesahkan Undang-Undang Pemilu pada 15 Agustus 2017 dan diundangkan oleh Menkumham Yasonna Laoly sehari setelahnya. Dengan adanyan UndangUndang Pemilu tersebut, Undang-Undang Nomor 42 Tahun 2008 tentang Pilpres, Undang-Undang Nomor 15 Tahun 2011 tentang Penyelenggaraan Pemilu, Undang-Undang Nomor 8 Tahun 2012 tentang Pileg, Pasal 57 dan 60 Ayat 1, 2 serta 4
Undang-Undang Nomor 11 Tahun 2006 tentang Pemerintahan Aceh dicabut dan dinyatakan tidak berlaku (Kumparan, 2018).

Komisi Pemilihan Umum yang disingkat dengan KPU adalah penyelenggara pemilu yang berkarakter nasional, tetap dan mandiri dalam menyelenggarakan Pemilihan Umum. Menurut Undang-Undang Nomor 7 Tahun 2017 Pasal 12-13 tentang Penyelenggaraan Pemilu, Tugas KPU yaitu merencanakan dan mempersiapkan pelaksanaan Pemilihan Umum, menyusun Peraturan KPU untuk setiap tahapan Pemilu, mengkoordinasikan, menyelenggarakan, mengendalikan dan memantau semua tahapan pemilu. Kewenangan KPU yaitu menetapkan Peraturan KPU untuk setiap tahapan Pemilu, menetapkan Peserta Pemilu, menetapkan dan mengumumkan hasil rekapitulasi penghitungan suara, menerbitkan keputusan KPU untuk mengesahkan hasil Pemilu dan mengumumkannya.

Kemudian Peraturan KPU yang disingkat dengan PKPU, adalah salah satu bagian dari peraturan perundang-undangan yang ada di Indonesia, yang menjadi otoritas kebijakan lembaga KPU untuk menyusunnya dalam rangka menyelenggarakan Pemilihan Umum. Peraturan KPU itu sendiri adalah penjelasan dari implementasi dari peraturan perundang-undangan sepertimana yang disebutkan dalam pasal 75 ayat 1 dan ayat 2 Undang-Undang Nomor 7 Tahun 2017 tentang Pemilihan Umum. Disebutkan bahwa: "untuk menyelenggarakan Pemilu sebagaimana yang diatur dalam Undang-Undang ini, KPU membentuk Peraturan KPU dan Keputusan KPU”.

Maka dapat di ambil kesimpulan bahwa Peraturan KPU diakui keberadaannya dan mempunyai kepastian dan kekuatan hukum yang mengikat sepanjang diperintahkan oleh peraturan perundang-undangan yang lebih tinggi (Undang- 
Undang Pemilihan Umum) atau dibuat berdasarkan kewenangan dan kebijakan yang diberikan oleh Undang-Undang kepada KPU serta tidak bertentangan dengan Undang-Undang yang berada di atasnya.

Peraturan KPU Nomor 36 Tahun 2018 tentang perubahan atas Peraturan KPU Nomor 3 tahun 2018 tentang pembentukan dan tata kerja PPK, PPS, KPPS, merupakan salah satu dasar hukum yang harus diperhatikan KPU kabupaten/kota dalam merekrut anggota PPK, PPS dan KPPS dengan ketentuan persyaratan yang tertulis dalam peraturan aquo.

Kemudian ketika pelaksanaan Pemilu 2019 kemarin terdapat banyak sekali kasus permasalahan yang terjadi salah satunya yang paling utama banyaknya yang meninggal para anggota KPPS. Seperti yang kami kutip, siaran pers Kementrian Kesehatan yang diterima di Jakarta, Kamis 16 Mei 2019 di 28 Provinsi: "data Kementrian Kesehatan melalui Dinas Kesehatan tiap Provinsi mencatat petugas KPPS yang sakit telah mencapai 11.239 orang dan korban meninggal 527 jiwa"(Gatra, 2019).

\section{Metode Penelitian}

Penelitian ini adalah penelitian hukum normatif, yaitu penelitian terhadap aturan perundang-undangan mengenai suatu gejala hukum tertentu, dalam hal ini aturan yang dimaksud mengenai Peraturan KPU Nomor 36 Pasal 36 Tahun 2018 tentang persyaratan menjadi anggota Panitia Pemilihan Kecamatan (PPK) dan Panitia Pemungutan Suara (PPS), dan anggota Kelompok Penyelenggara Pemungutan Suara (KPPS). Metode pendekatan dalam penelitian ini adalah pendekatan kasus (case approach) yang bertujuan untuk mengkaji penerapan norma hukum positif dalam praktik hukum, khususnya kasus-kasus yang telah diputus sebagaimana dapat diamati dalam yurisprudensi pada kasus-kasus yang menjadi fokus penelitian, kemudian juga menggunakan pendekatan konseptual (conseptual approach) yang dilakukan dengan dikembalikannya pada prinsipprinsip hukum. Dan data yang telah diperoleh dianalisis secara kualitatif untuk memdapatkan jawaban atas permasalahan yang diteliti.

\section{Hasil dan Pembahasan}

Dalam penelitian ini penulis fokus terhadap Peraturan Komisi Pemilihan Umum (PKPU) Nomor 36 pasal 36 Tahun 2018 tentang persyaratan menjadi anggota Panitia Pemilihan Kecamatan (PPK), Panitia Pemungutan Suara (PPS) Dan Kelompok Penyelenggaraan Pemungutan Suara (KPPS) pasca penyelenggaraan Pemilu 2019 dianalisis dalam perspektif Maqashid Syariah. Sebelumnya penulis ingin menganalisis faktorfaktor yang melatarbelakangi timbulnya kejadian dengan banyaknya para petugas Pemilu yang jatuh sakit sampai banyaknya juga yang meninggal dunia. Yang pertama dikarenakan Pemilu tahun 2019 berbeda dengan Pemilu sebelumnya yang mana pada Pemilu 2019 awal dimulainya Pemilu dengan sistem Pemilihan Serentak. Ketika diputuskannya oleh Mahkamah Konstitusi Nomor 14/PUU-XI/2013 maka terjadinya penggabungan pemilihan umum legislatif dengan pemilihan umum presiden dan wakil presiden di tahun 2019 dan seterusnya. Pelaksanan Pemilu serentak pada tanggal 17 April 2019, masyarakat Indonesia yang menjadi pemilih mencoblos lima (5) surat suara yaitu; surat suara Presiden dan Wakil Presiden, surat suara DPR, surat suara DPD, surat suara DPRD Provinsi, dan surat sura DPRD Kab/kota. Sejarah digelarnya Pemilu serentak berawal dari aksi Effendi Ghozali dan Koalisi Masyarakat untuk Pemilu serentak. Pada 2013 mereka menggugat UU No 42 Tahun 2008 tentang Pilpres ke Mahkamah 
Konstitusi. Gugatan itu teregister dengan Nomor 14/PUU-XI/2013. Alasan mereka sederhana, penyelenggaraan Pemilu serentak lebih efisien baik dari segi waktu maupun biaya. Singkatnya, MK mengabulkan sebagian gugatan tersebut. Majelis Hakim MK membatalkan Pasal 3 Ayat 5, Pasal 12 Ayat 1 dan 2, Pasal 14 Ayat 2 dan Pasal 112 Undang-Undang Pilpres yang mengatur pelaksanaan Pilpres 3 bulan setelah pelaksanaan Pileg alias tidak serentak. Akibat putusan itu, pemerintah melalui Kementrian Dalam Negeri (Kemendagri) langsung menyusun UndangUndang Pemilu yang baru dengan memasukkan ketentuan pemilu serentak. Selanjutnya, Presiden Joko Widodo mengesahkan Undang-Undang Pemilu pada 15 Agustus 2017 dan diundangkan oleh Menkumham Yasonna Laoly sehari setelahnya. Dengan adanyan Undang-Undang Pemilu tersebut, Undang-Undang Nomor 42 Tahun 2008 tentang Pilpres, Undang-Undang Nomor 15 Tahun 2011 tentang Penyelenggaraan Pemilu, Undang-Undang Nomor 8 Tahun 2012 tentang Pileg, Pasal 57 dan 60 Ayat 1, 2 serta 4 UndangUndang Nomor 11 Tahun 2006 tentang Pemerintahan Aceh dicabut dan dinyatakan tidak berlaku (Kumparan, 2018).

Ketika pelaksanaan Pemilu serentak pada 17 April 2019, KPPS memiliki beban kerja yang meningkat dibanding dengan Pemilu tahun 2014 yang lalu. Hal ini dikarenakan KPPS harus melakukan pemungutan dan penghitungan terhadap 5 surat suara per pemilih. KPPS melakukan tugasnya di satu TPS (Tempat Pemungutan Suara). Jumlah maksimal pemilih setiap TPS nya sudah ditentukan dalam undangundang KPU No. 7 Tahun 2017 yang mengatur bahwa pemilih yang berada di TPS tidak lebih dari 300 pemilih. Artinya bila diakumulasikan ada maksimal 1500 surat suara yang menjadi beban kerja KPPS pada Pemilu tahun 2019. Sedangkan jumlah KPPS di satu TPS berdasarkan Pasal 59 Undang-undang No. 7 tahun 2017 berjumlah 7 orang. Jadi masing-masing KPPS bertanggung jawab untuk melakukan pemungutan dan penghitungan suara maksimal 214-215 surat suara dan merupakan beban kerja bagi masing masing KPPS. Beban kerja KPPS termasuk juga berasal dari tekanan beberapa pihak, seperti adanya tekanan dari badan penyelenggara di atasnya dan peserta pemilu (Pandiangan, 2019). Jadi beban kerja KPPS di Pemilu tahun 2019 sangat tinggi dan berat. Banyaknya surat suara yang harus diambil dan dihitung oleh KPPS ini menyebabkan waktu kerja KPPS menjadi panjang dan lama, yaitu sekitar 1824 jam (Maharani, 2019) pada saat penyelenggaraan Pemilu serentak pada 17 April 2019.

Harus kita sadari bahwa KPPS menjadi salah satu peran yang sangat penting dalam pelaksanaan pemungutan dan penghitungan suara di Pemilu 2019. Termasuk melayani hak pilih masyarakat. Hasil kinerja KPPS akan sangat menentukan kualitas Pemilu 2019 dan berpeluang akan digugat oleh masyarakat dan peserta Pemilu 2019 bila penyelenggaraan Pemilu tidak memenuhi prinsipprinsip: mandiri, jujur, adil, berkepastian hukum, tertib, terbuka, proporsional, profesional, akuntabel, efektif dan efisien. Tugas, wewenang dan kewajiban KKPS yang demikian luas dan berat pada Pemilu 2019 kiranya diimbangi dengan perubahan organisasi dan fasilitas serta kesejahteraan yang diterima oleh Ketua dan Anggota KPPS (Pandiangan, 2019).

Kemudian kedua penulis menganalisis dari segi aturan yang dibuat oleh KPU yaitu Peraturan Komisi Pemilihan Umum (PKPU) Nomor 36 pasal 36 Tahun 2018 tentang persyaratan menjadi anggota Panitia Pemilihan Kecamatan (PPK), Panitia Pemungutan Suara (PPS) dan Kelompok Penyelenggaraan Pemungutan Suara (KPPS) 
Penyelenggaraan Pemilihan Umum dalam perspektif Maqashid Syariah.

Pertama, pada Pasal 36 ayat 1 huruf g PKPU Nomor 36 Tahun 2018, syarat menjadi anggota PPK, PPS dan KPPS yaitu; "Mampu secara Jasmani, Rohani dan Bebas dari penyalahgunaan Narkotika". Tidak dijelaskan secara lebih terperinci mengenai kesehatan jasmani dan rohani dari anggotanya seperti disertai surat keterangan sehat dari pihak yang yang berwenang sehingga pasca Pemilu Serentak 2019 ini terdapat banyak sekali kasus terutama meninggalnya para anggota KPPS. Seperti yang kami kutip, siaran pers Kementrian Kesehatan yang diterima di Jakarta, Kamis 16 Mei 2019 di 28 Provinsi: (Gatra, 2019) "data Kementrian Kesehatan melalui Dinas Kesehatan tiap Provinsi mencatat petugas KPPS yang sakit telah mencapai 11.239 orang dan korban meninggal 527 jiwa". Persyaratan jadi anggota KPPS sedianya tidak diturunkan, Taufan Damanik mengatakan faktor kelalaian yang dimaksud itu juga mencakup penurunan standar regulasi persyaratan anggota KPPS, khususnya syarat mampu secara jasmani dan rohani, serta bebas dari penyalahgunaan narkotika. Semula dibutuhkan hasil pemeriksaan rumah sakit atau puskesmas untuk memenuhi syarat itu, tetapi kemudian diganti dengan surat pernyataan dari yang bersangkutan. Seperti yang disampaikan oleh Komnas Hak Asasi Manusia (HAM) yang merilis hasil pemantauan terkait petugas penyelenggara Pemilu 2019 yang sakit dan meninggal dunia. Dari hasil pemantauan, Komnas HAM menemukan adanya faktor kelalaian terkait standar persyaratan petugas Kelompok Penyelenggara Pemungutan Suara (KPPS). Pemantauan dilakukan setelah Komnas HAM menerima sejumlah laporan dari masyarakat terkait meninggalnya ratusan petugas KPPS. Tim pemantauan Pemilu 2019 Komnas HAM secara serentak melakukan pemantauan di Jawa Barat,
Jawa Tengah, Jawa Timur dan Banten pada 15-18 Mei 2019. "bahwa Komnas HAM RI melihat faktor kelalaian dengan menurunkan standar regulasi persyaratan KPPS tentang syarat mampu secara jasmani dan rohani serta bebas dari penyalahgunaan narkoba dari yang semula berdasarkan hasil pemeriksaan rumah sakit atau puskesmas bisa diganti dengan surat pernyataan dari yang bersangkutan, sebagaimana ketentuan Pasal 72 huruf g Undang-Undang Nomor 7 Tahun 2017 tentang Pemilu jo. Pasal 36 ayat 1 huruf g PKPU Nomor 36 Tahun 2018 mengatur bahwa syarat untuk menjadi anggota PPK, PPS, dan KPPS adalah mampu secara jasmani, rohani dan bebas dari penyalahgunaan narkotika" kata Ketua Komnas HAM Ahmad Taufan Damanik membacakan hasil pemantauan petugas penyelenggara Pemilu 2019, di kantor Komnas HAM, jalan Latuharhary, Jakarta Pusat, Selasa, 21 Mei 2019 (Rolando, 2019).

Kedua, dilihat dari proses rekrutmen terutama pada soal usia hanya mensyaratkan minimal 17 tahun, sedangkan batas usia maksimal tidak diatur situasi ini menjadi salah satu faktor kerentanan terhadap penyelenggara sebab usia ratarata petugas KPPS yang meninggal dari data komnas HAM di atas 40 tahun (Wardah, 2019). Menurut Ahmad Taufan Damanik sebagai ketua Komnas HAM mengatakan pihaknya menemukan fakta adanya pengabaian terhadap perlindungan kesehatan bagi petugas KPPS, Pengawas, dan aparat keamanan dalam pelaksanaan pemungutan suara pada Pemilu 2019. "Sehingga mereka ketika bermasalah secara fisik, sakit, tidak mendapat prioritas penanganan. Laporan-laporan di lapangan itu, sudah sakit tidak ada yang bertanggung jawab. Mereka harus mengurus diri sendiri kerumah sakit. Kalau kondisinya cukup parah, tentu biaya penobatannya besar, tidak semua bisa ditanggung oleh BPJS." Kata Taufan Damanik. Hal ini 
diperparah karena tidak ada keterlibatan pemerintah untuk menanggung biaya pengobatan. Baru belakangan ada surat edaran yang menyatakan akan menanggung biaya pengobatan, meskipun hal itu belum efektif karena sampai sekarang petugas KPPS masih berobat dengan biaya sendiri. Komnas HAM menilai belum ada langkah terpadu, baik dari KPU dan BAWASLU, maupun Kementrian Kesehatan, untuk mengantisipasi jatuhnya korban secara masal.

Dari uraian contoh kasus di atas merupakan gambaran yang dapat menunjukan bahwa Peraturan KPU dalam menetapkan syarat menjadi anggota KPPS kurang menjelaskan makna dan maksud secara terperinci dari setiap isi yang terdapat di dalam peraturan tersebut, sehingga banyak terjadi permasalahan yang pada intinya terdapat pada peraturan itu sendiri. Kemudian jika diambil dari salah satu ungkapan teori dari Marcus Tullius Cicero pernah berujar sebagai berikut "salus populi suprema lex esto" yang artinya adalah keselamatan rakyat merupakan hukum tertinggi. Jika ditautkan dengan tujuan berdirinya suatu negara adalah untuk menciptakan keamanan, ketertiban dan mengusahakan kesejahteraan serta kemakmuran rakyat. Dalam konteks ini negara dengan organ-organ yang dimiliki, mempunyai peran melalui tugas dan fungsinya masing-masing untuk menciptakan keamanan, ketertiban dan mengusahakan kesejahteraan serta kemakmuran rakyat. Keselamatan dan kemakmuran rakyat merupakan tujuan utama bernegara. Di negara Indonesia tujuan tersebut termaktub dalam Alinea ke 4 pembukaan Undang-Undang Dasar Negara Republik Indonesia yang bunyinya "membentuk suatu Pemerintah Negara Indonesia yang melindungi segenap bangsa Indonesia... untuk memajukan kesejahteraan umum, mencerdaskan kehidupan bangsa, dan ikut melaksanakan ketertiban dunia yang berdasarkan kemerdekaan, perdamaian abadi, dan keadilan sosial" lebih tegas. Namun seperti yang kita ketahui pada tataran implementasi atau secara realitas asas "salus populi suprema lex esto" tidak sepenuhnya direalisasikan bahkan asumsi yang extreme menyatakan bahwa hal itu hanyalah suatu mimpi belaka (Setiawan, 2018).

Selanjutnya penulis akan menganalisis kejadian ini dalam perspektif Maqashid Syariah, tujuan hukum itu sering disebut dengan Maqashid Syariah yaitu tujuan syariat dalam menetapkan hukum. Tujuan hukum tersebut dapat dipahami melalui penelusuran terhadap sumber hukum Islam sendiri seperti ayat-ayat al-Qur'an dan Hadits Rasulullah SAW. Penelusuran yang dilakukan ulama Ushul Fiqh tersebut menghasilkan kesimpulan bahwa tujuan syariat dalam menetapkan hukum adalah untuk kemaslahatan manusia baik untuk di dunia dan di akhirat. Menurut Imam al-Syathibi, kemaslahatan dapat diwujudkan apabila terpeliharanya lima unsur yaitu menjaga agama, jiwa, akal, keturunan dan harta. Tujuan utama syariat Islam terletak pada perlindungan terhadap lima unsur tersebut. Kelima pokok tersebut merupakan suatu hal yang harus selalu dijaga, dipelihara serta dilindungi dalam kehidupan ini untuk mencapai sebuah kemaslahatan yang merupakan konsep tujuan dari Maqashid Syariah (Kadir \& Yunia, 2014). Jika kita melihat dari pembagian tingkatan dari Maqashid Syariah itu sendiri maka penulis menyimpulkan bahwa kasus atau permasalahan ini termasuk dalam tingkatan yang pertama yaitu ad-dharuriyyat yang artinya bahwa untuk menetapkan suatu kemaslahatan, tingkat keperluannya harus diperhatikan, apakah akan sampai mengancam eksistensi lima prinsip pokok mașlahah atau belum sampai pada batas tersebut yaitu Hifz ad-din (memelihara Agama), Hifdz an-nafs (memelihara Jiwa), Hifz al-aql (memelihara akal), hifz an-nasab 
(memelihara keturunan), Hifz al-maal (memelihara harta).

Kemudian penulis menganalisis kasus atau kejadian ini menggunakan 5 prinsip di atas yaitu; pertama Hifdz Diin (Pemeliharaan agama), di dalam Islam agama merupakan pedoman hidup bagi seluruh Muslim, maka daripada itu ketika Muslim mengambil keputusan harus mempertimbangkan apakah Agama Islam bisa terpelihara dan bisa melaksanakan perintah dan menjauhi larangan-Nya sehingga tidak merusak aqidah. Sebagaimana umat beragama dan saling bertoleransi agar kiranya Negara memberikan ruang atau kesempatan bagi para petuugas untuk mengerjakan kewajibannya selaku umat Islam untuk mengerjakan sholat lima waktu. Apabila dilihat dengan padatnya tugas dan kewajibannya harus dilakukan oleh para petugas dari persiapan, pelaksanaan dan selesainya pelakasanaan yang lebih berat tugas untuk menghitung hasil pemilihan. Dengan demikian hendaknya kemaslahatan yang dituju harus ditercapai dengan salah satunya memenuhi hak seorang muslim untuk melaksanakan kewajibannya untuk beribadah kepada tuhannya. Maka apabila pemeliharaan terhadap agama ini tidak tercapai maka kemaslahatan juga tidak akan teracapai. Yang kedua Hifdz An-Nafs (Memelihara Jiwa) jika kita kaitkan dengan Peraturan KPU yang di buat oleh KPU dalam pemeliharaan jiwa atau disebut dengan hifdzun nafs harus direalisasikan dan diberikan kepada para petugas Pemilu, apabila dilihat dengan kejadian yang terjadi ketika Pemilu kemarin yang terjadi banyak sekali korban jiwa dikarenakan faktor kelelahan dan banyaknya tugas dan kewajibannya harus dikerjakan, sehingga sedikit sekali waktu para petugas untuk beristirahat. Kemudian faktor yang lain yakni faktor umur dari para petugas juga tidak dilihat sehingga banyak yang terjadi kelelahan hingga merenggut nyawa dikarenakan faktor umur mereka yang sudah tua, dan harusnya faktor umur juga menjadi faktor penting jangan sampai mencari petugas Pemilu dengan kategori tua, hendaknya di Peraturan KPU diatur mengenai batasan umur sebagai syarat untuk menjadi petugas KPU. Dan harusnya juga ketika hendak melamar menjadi petugas harus disertakan dengan surat keterangan sehat yang resmi atau mungkin dari pihak Negara memberikan fasilitas tersebut dan benar-benar diperiksa kesehatan para petugas. Jangan sampai Negara membiarkan ini karna menjaga jiwa setiap individu merupakan tanggung jawab Negara juga. Jadi apabila dilihat dari sisi Maqashid Syariah maka tidaklah tercapai untuk mendapatkan kemaslahatannya dalam menjaga jiwa. Hendaknya Negara atau institusi terkait untuk menjamin dan menjaga jiwa, kesehatan dan kemaslahatan bagi para petugas Pemilu. Adapun yang ketiga hifdz al-'aql (memelihara akal), apabila kita kaitkan dengan permasalahan yang ada, maka juga haruslah Negara untuk memikirkan para petugas dengan kerja beban yang amat berat seperti mana yang telah disampaikan dan dijelaskan pada prinsip menjaga jiwa karna jiwa dan akal selalu bersama dalam bekerja jadi hendaknya Negara juga memikirkan kemaslahatan untuk para petugas Pemilu agar tidak terjadi lagi masalah dikemudian harinya. Yang keempat Hifdz An-Nasb (Memelihara Keturunan) jika prinsip pertama, kedua dan ketiga sudah tidak terpenuhi atau terjadi timbulnya mafsadat atau kerusakan pastilah dalam memelihara keturunan tidak akan tercapai maslahat atau kebaikannya, karena pada dasarnya jika kita ingin melangsungkan kehidupan dengan meneruskan keturunan maka barang tentu jiwa dan akal kita harus terpelihara dengan baik dan tidak lepas pula dari terpeliharanya agama karena aturan agama merupakan ketetapan dari Allah Swt yang harus dikerjakan apa yang diperintahkan dan tidak 
mengerjakan apa yang dilarang. Dan orang yang beragama Islam meyakini bahwa Allah SWT memberikan syariat tidak lain dan tidak bukan untuk kemaslahatan dan kesejahteraan umat manusia. Yang kelima adalah memelihara harta atau disebut dengan hifdzul maal, aspek yang terakhir ini tentunya tidak asing dan tidak kalah penting dipertimbangkan apabila terjadi pengambilan keputusan dengan mengusung konsep Maqashid Syariah. Karena di era globalisasi ini ekonomi adalah salah satu aspek yang utama yang harus dilindungi. Apabila dihubungkan juga dengan permasalahan para petugas Pemilu maka sejatinya salah satu tujuan mereka bekerja menjadi petugas untuk memenuhi kebutuhan ekonomi mereka dengan nominal gaji yang tidak besar dan juga dibebankan dengan tugas yang berat maka tidaklah tercapainya kemaslahatan bagi para petugas. Harusnya negara menyeimbangkan antara hak dan kewajiban dengan salah satunya menaikkan upah gaji para petugas bukan malah terjadinya mafsadat atau kerusakan dengan banyaknya permasalahan jadi sekali lagi hendaknya para petinggi Negara untuk memberikan kesejahteraan dan kemaslahatan bagi warga negara nya terutama para petugas Pemilu.

Sepertimana dalam sebuah kaidah Ushul Fiqh yang berbunyi "dar'ul mafaasidh muqoddamun 'ala jalbil mashoolih" yang artinya meninggalkan kemudharatan atau kerusakan lebih diutamakan daripada mengambil manfaat. Jadi para pemangku kebijakan sebelum membuat atau memutuskan sebuah peraturan haruslah untuk melihat terlebih dahulu antara sisi kemudharatan atau kerusakan dengan kemaslahatan. Sesuai dengan kaidah Ushul Fiqh yang disebutkan "tasharruful imam manuuthun bil maslahah" yang artinya adalah kebijakan seorang pemimpin terhadap rakyatnya tergantung pada kemaslahatan (Kurdi, 2015). Tindakan dan kebijaksanaan yang ditempuh oleh pemimpin atau penguasa harus sejalan dengan kepentingan umum bukan untuk golongan atau untuk diri sendiri, maka pemimpin harus adil terhadap keputusan yang dibuat sehingga tujuan untuk menimbulkan kemaslahatan dapat terwujud.

\section{Kesimpulan}

Dari pembahasan yang sudah penulis jelaskan sebagaimana di atas, maka dapatlah diambil kesimpulan bahwa implementasi Peraturan KPU Nomor 36 Pasal 36 Tahun 2018 pada Pemilu 2019 dalam perspektif Maqashid Syariah nyatanya banyak menimbulkan kemudharatan yaitu sistem Pemilihan pada tahun 2019 adalah menggunakan sistem Pemilihan serentak kemudian dari beberapa ayat dalam pasal aquo di antaranya Pasal 36 ayat 1 huruf g PKPU Nomor 36 Tahun 2018, syarat menjadi anggota PPK, PPS dan KPPS yaitu; "Mampu secara Jasmani, Rohani dan Bebas dari penyalahgunaan Narkotika" yang mana tidak dijelaskan secara lebih terperinci mengenai kesehatan jasmani dan rohani dari anggotanya seperti disertai surat keterangan sehat dari pihak yang yang berwenang kemudian Pasal 36 ayat 1 huruf $b$ yaitu berusia paling rendah 17 Tahun tidak dijelaskan batasan terakhir usia sehingga banyak dari para petugas Pemilu berusia lanjut bahkan lebih dari 40 tahun ke atas. Selanjutnya dianalisis dari 5 prinsip ad-dharuriyyat yang mana hifz ad-din (memelihara Agama), hifdz an-nafs (memelihara Jiwa), hifz al-aql (memelihara akal), hifz an-nasab (memelihara keturunan), hifz al-maal (memelihara harta) tidak terpenuhi.

Dengan kejadian atau peristiwa yang terjadi pada Pemilu serentak 2019 ini diharapkan kepada KPU selaku lembaga yang menjalankan penyelenggaran Pemilu menjadi bahan evaluasi agar tidak terjadi atau meminimalisirkan kejadian masalah dikemudian hari dan harus adanya 
perbaikan baik dari aturan yang KPU buat yang mana semuanya harus mementingkan kemaslahatan. Selanjutnya harus ada kontrol yang serius dari berbagai pihak yang berwajib seperti Dewan Kehormatan Penyelenggara Pemilu (DKPP) lembaga yang bertugas menangani pelanggaran kode etik penyelenggaraan Pemilu serta sebuah lembaga yang dikhususkan untuk mengimbangi dan mengawasi kinerja dari Komisi Pemilihan Umum (KPU) dan Badan Pengawas Pemilu (BAWASLU) kemudian Kementrian Kesehatan untuk memperhatikan, mengawasi, menindak lanjuti dan memberikan keterangan izin kesehatan serta memberikan perlindungan kesehatan kepada anggota penyelenggara pemungutan suara (KPPS) Mahkamah Konstitusi Republik Indonesia untuk mengadili, menerima, serta memutuskan perkara yang terjadi pada Pemilu serta masyarakat untuk mendapatkan kepastian hukum, perlindungan dan keadilan dalam penyelenggaraan Pemilu.

\section{Daftar Pustaka}

Gatra, S. (2019). Data Kemenkes: 527 Petugas KPPS Meninggal, 11.239 Orang Sakit. Kompas.

https://nasional.kompas.com/read/2019/05/16 /17073701/data-kemenkes-527-petugaskpps-meninggal-11239-orang-sakit?page=all

Kadir, A., \& Yunia, I. (2014). Prinsip Dasar Ekonomi Islam Perspektif Maqsidh Syariah. PT. Fajar Interpratama Mandiri.

Kumparan. (2018). Memahami Lagi Alasan Pilpres dan Pileg Digelar Serentak Tahun 2019. Kumparan.

https://kumparan.com/kumparannews/mema hami-lagi-alasan-pilpres-dan-pileg-digelarserentak-tahun-2019-1542495076123429491

Kurdi, M. (2015). Ushul Fiqh Sebuah Pengenalan Awal. Lembaga Naskah Aceh.

Maharani, D. (2019). Bekerja 18-24 Jam, Petugas KPPS di Sleman Keluhkan Honor Belum Cair. Kompas. https://regional.kompas.com/read/2019/04/19 /21524241/bekerja-18-24-jam-petugas-kppsdi-sleman-keluhkan-honor-belumcair?page $=$ all

Pandiangan, A. (2019). Kelompok Penyelenggara Pemungutan Suara (Kpps) Pemilu 2019: Tanggungjawab Dan Beban Kerja. The Journal of Society \& Media, 3(1), 17. https://doi.org/10.26740/jsm.v3n1.p17-34

Rolando. (2019). Komnas HAM Temukan Faktor Kelalaian Terkait Standar Regulasi KPPS. DetikNews. https://news.detik.com/berita/d4558492/komnas-ham-temukan-faktorkelalaian-terkait-standar-regulasi-kpps

Setiawan, A. (2018). Terlupakannya Asas Keselamatan Rakyat Adalah Hukum Tertinggi. Metro Jambi. https://metrojambi.com/read/2018/12/13/381 64/terlupakannya-asas-keselamatan-rakyatadalah-hukum-tertinggi/

Wardah, F. (2019). Komnas HAM: Negara Abai terhadap Perlindungan Kesehatan Petugas KPPS. VOA Indonesia. https://www.voaindonesia.com/a/komnasham-negara-abai-terhadap-perlindungankesehatan-petugas-kpps/4926392.html 